\title{
Analysis of student perceptions of problem-solving learning and peer assessment
}

\author{
Yustinus Maksimilianus Dhey Nesi ${ }^{a}$, Sentot Kusairi ${ }^{b} *$, Arrika Wifqotu Lailin Nafisah c \\ Universitas Negeri Malang. Jl. Semarang 5 Malang, 65145 Indonesia \\ a justinlannesi@gmail.com; ${ }^{b}$ sentot.kusairi.fmipa@um.ac.id; c arrikavisa97@gmail.com \\ *Corresponding Author
}

Received: 7 October 2021; Revised: 23 November 2021; Accepted: 3 January 2022

\begin{abstract}
Problem-solving is one of the mandatory skills for students in the 21st century, especially in physics subjects. This study aims to determine the students' ability to solve parabolic motion problems, determine students' perceptions of learning in solving parabolic motion problems, investigate the results of peer assessments carried out by students, and determine students' perceptions of the implementation of peer assessment. This research method uses qualitative research procedures with a phenomenological approach. This research was conducted on 25 high school students in the Ende district. The results of data analysis showed that the article met four indicators of problem-solving ability according to Polya, namely understanding the problem, planning a solution, solving the problem according to plan, and re-checking the evaluation results. The problem ability of students in this study was obtained with the results of 53.06 being included in the sufficient category. Future studies should give priority to providing instruction and training before giving peer assessment.

Keywords: Student's Perception Questionnaire, Peer Assessment, Problem-solving Ability
\end{abstract}

How to Cite: Nesi, Y. M. D., Kusairi, S., \& Nafisah, A. W. L. (2022). Analysis of student perceptions of problem-solving learning and peer assessment. Momentum: Physics Education Journal, 6(1), 73-85. https://doi.org/10.21067/mpej.v6i1.6005

\section{Introduction}

Problem-solving skills and strategies for solving them are the basic skills that students must possess (Scherer \& Beckmann, 2014; Shin et al., 2021). As a 21st-century skill, problem-solving link conceptual mastery with students' practical skills (Freitas et al., 2004) and apply scientific reasoning to ideas and problem-solving strategies (Park, 2020). Students who are creative, collaborative (Berge \& Danielsson, 2013; Jamaludin \& Hung, 2017) and able to work together in social spaces (PöysäTarhonen et al., 2021) are characteristics of students who are able to solve problems (Bahar et al., 2021; Spoon et al., 2021).

Students' problem-solving abilities can be improved by selecting suitable learning strategies and models (Milbourne \& Wiebe, 2018). For teachers, the learning model in question is crucial, allowing students to participate in the learning process (Demirhan \& Sahin, 2021). The use of problem-based and project-based learning models is the teacher's choice in growing students' problem-solving abilities (Tan et al., 2019).

The phenomenon of student involvement in learning so far has only been seen from the point of view of the learning model used but not by giving an assessment (Alias et al., 2015). Student-based assessment is the most widely used assessment model in measuring students' problem-solving concepts (Alias et al., 2015; Fadhilah et al., 2019). Teachers more often use this form of assessment to see the level of students' conceptual understanding (Sluijsmans et al., 2001). Teachers have not optimized the assessment function as a learning activity (assessment as learning, assessment for 
learning) to provide value and reflection on learning activities (Ploegh et al., 2009). This function is a form of purpose from the use of peer assessment (PA) (Alias et al., 2015) and student perception questionnaires in learning (Omar et al., 2018).

Peer assessment and student perception questionnaires are forms of participatory assessment (Alias et al., 2015) in which students are involved in contributing to the work of their peers (Heredia et al., 2016), providing input (Hansen, 2020), and learning reflection (Adarkwah, 2021). As a process, peer assessment and student perception questionnaires combine several student perspectives and develop them into new perspectives (Ploegh et al., 2009) and improve student performance (Zhang, 2020). This allows for reflection of learning by teachers and students in the classroom (Adarkwah, 2021) with the teacher's openness to accept student criticism (Tan et al., 2019). The criticism made by students as a form of learning reflection is the main goal of secondary and higher education (Laskar \& Robutel, 2000). Giving feedback as a form of learning reflection greatly influences the student learning process (Wancham \& Tangdhanakanond, 2020).

Peer assessment (PA) forms students into effective and active learners (Bloxham \& West, 2004; Lu \& Law, 2012; Miller, 2003; Panadero \& Dochy, 2014). Peer assessment is a series of activities through which individuals consider the amount, level, value, quality, or success of a product or learning outcome and make judgments about the work of others (Reinholz, 2016). Peer assessment is able to improve student communication with other students in solving problems based on the feedback provided (Lu \& Law, 2012). (Ploegh et al., 2009) stated that the achievement of learning outcomes through peer assessment can be obtained by involving students in learning by searching for and interpreting the evidence found in the learning process. The process of finding and interpreting the evidence is the main skill of students as learners (Miller, 2003). Peer assessment has many advantages (Ketonen et al., 2020; Ploegh et al., 2009; Yurdabakan \& Olgun, 2011). Peer assessment is carried out based on clear and objective criteria (Liu \& Carless, 2006). Therefore, peer assessment by students in class needs to be carried out through the following steps (Edwards, 2013; Miller, 2003; Ploegh et al., 2009), namely: determining the competence or aspect of ability to be assessed through peer assessment, determining the assessment criteria that will be used in peer assessment, formulating an assessment format (can be in the form of scoring guidelines, check mark lists, or rating scales), asking students to conduct peer assessments objectively, asking the teachers to review the results of the assessment to encourage students to always conduct peer assessments carefully and objectively (Omar et al., 2018), providing feedback to students based on the results of studies on peer assessment (Leeuwenkamp et al., 2019; Lu \& Law, 2012; Omar et al., 2018), drawing conclusions on the results of the assessment by using peer assessment related to the achievement of the spiritual and social attitude competencies of students, and following up with the reference to the results of the assessment through peer assessment (Tapingkae et al., 2020).

Students in their involvement also obtain students' problem-solving abilities during learning (Kelly, 2007). Student involvement in the learning process can be seen in various forms, such as attention, concrete actions in the form of participation in learning activities such as unpacking problems, doing tasks given by the teacher (L. M. Daniels et al., 2021) and in formative and summative assessment activities (Guiaya \& Bueno, 2019). Student involvement is a manifestation of motivation seen through students' actions, cognitive, and emotions (Nouwen \& Clycq, 2019). Student involvement is always in 3 domains: attitude, cognitive, and emotional (Jones \& Carter, 2019). These three components are interrelated dynamically within the individual (Quin et al., 2017). Attitude, emotional and cognitive components share characteristics about how students act, feel and think (L. M. Daniels et al., 2021; Jones \& Carter, 2019). However, peer assessment and student perception questionnaires, as a form of assessment of the learning process (Edwards, 2013; Liu \& Carless, 2006; Molway, 2021; Omar et al., 2018; Papinczak et al., 2007; Sluijsmans et al., 2001) has never been conducted together.

Students' perceptions of the learning process (Molway, 2021) and the effectiveness of the use of peer assessment (Omar et al., 2018) are one ways to improve the quality of learning (Veugen et al., 2021) and student learning outcomes (Leeuwenkamp et al., 2019). Student perception questionnaires can increase students' self-confidence and responsibility because assessors who know exactly 
about students are students themselves, and students become the best assessors of their own work (Ezzahra et al., 2015). So far, evaluation of student success in the learning process is usually carried out by teachers and students as objects of evaluation (Hansen, 2020; Hansen \& Ringdal, 2018; Laskar \& Robutel, 2000; Schildkamp et al., 2020; Voinea, 2018). Therefore, the data obtained has not shown a true reflection of students (Molway, 2021). For example, a teacher gives low grades to students who like to annoy their friends while the teacher is teaching. Here the teacher makes a decision not based on the student's own expertise but only on the attitude of the student that the teacher sees with the naked eye, while the teacher does not clearly recognize what or why the student is disturbing his friend.

As a form of feedback, student perception questionnaires and peer assessments promote active student involvement in learning (Chang, 2010). Student perception questionnaires and peer assessments are able to improve student performance in the classroom (Adarkwah, 2021) because the main factor in student perception questionnaires and peer assessments is that students are given the opportunity to "assess" themselves and their friends (Goh et al., 2016; Papinczak et al., 2007). Student perception questionnaires and peer-assessment are packaged in the form of an assessment of physics problem-solving skills (tests) and students' perceptions of learning in solving parabolic motion problems. The teacher as the subject of learning provides space for students to consider themselves and friends as an effort to reflect on the learning process. This research is expected to explore the basics of the assessment process, provide descriptive feedback, and maximize students' interpersonal skills. Assessment should be carried out further to consider the appropriate type of assessment in group discussion and classroom learning. Based on the description above, the objectives of this research are: (a) Knowing students' abilities in solving parabolic motion problems; (b) Knowing students' perceptions of learning in solving parabolic motion problems; (c) Knowing the results of peer assessment conducted by students; (d) Knowing students' perceptions of the implementation of peer assessment.

\section{Methods}

This research involves investigating quantitative descriptions of students' perceptions of problem-solving learning and peer assessment. Research subjects were given two problem-solving questions and then given a questionnaire on student perceptions of problem-solving learning. The problem-solving test is in the form of 2 problem-solving questions on the parabolic motion material. Before being tested on students, the problem-solving test has been validated by the validator, namely the supervisor. Problem-solving tests are checked by the teacher and also checked by students as a form of peer assessment activity. The results of the problem-solving test were then analyzed descriptively quantitatively. The problem-solving test scores, which contain two questions, are then interpreted in categories, as shown in Table 1.

Table 1. Score Category of Problem-Solving Ability Test Result According to Polya

\begin{tabular}{cccc}
\hline No. & Score Interval & Percentage & Category \\
\hline 1 & $0-20$ & $0-20$ & Very Low \\
2 & $21-40$ & $21-40$ & Low \\
3 & $41-60$ & $41-60$ & Moderate \\
4 & $61-80$ & $61-80$ & High \\
5 & $81-100$ & $81-100$ & Very High \\
\hline
\end{tabular}

After students complete the problem-solving test questions, students then fill out a questionnaire on student perceptions about the role of physics learning in problem-solving. This questionnaire was adapted from the Physport Student Assessment of their Learning Gains (SALG). This questionnaire contains ten indicators with 84 questions. There are three answer choices: not helpful, slightly helpful, and very helpful. Students give a checklist $(v)$ for each answer that the student chooses. The results of students' answers were then analyzed descriptively to determine students' perceptions of the role of physics learning in improving physics problem-solving abilities. 
After students fill out a student perception questionnaire, students then carry out peer assessment activities to check friends' answers using an assessment rubric prepared by the researcher and validated beforehand. Students use this assessment rubric as a benchmark in scoring other students' work. The assessment rubric contains the completion steps along with the scores given for each completed step that the students have done correctly. After conducting a peer assessment, students are then given a questionnaire on student perceptions of the peer assessment that has been done.

The questionnaire on student perceptions of peer assessment was adapted from the questionnaire developed by Omar et al. (2018). This student perception questionnaire contains 18 questions about students' perceptions of peer assessment in learning physics problem-solving. Students fill this questionnaire by giving a checklist $(v)$ for two answer choices, namely the answer "yes" and "no". After filling out the student perception questionnaire, the student's answers were then analyzed in a quantitatively descriptive way in order to discuss the research findings.

This research was conducted on 25 high school students in the Ende district. The instruments used in this study were physics problem-solving test questions for parabolic motion material, student perception questionnaires about the role of physics learning in problem-solving, problem-solving test assessment rubrics, and student perception questionnaires on peer assessment. The sampling technique was carried out using the purposive sampling technique. This is because the 25 students are used to solving physics problems through problem-solving tests because these 25 students are students in the superior class. In addition, the high school is a favourite school in the Ende district because it is a school that applies $5 \mathrm{M}$ learning (scientific approach) and hybrid learning during the pandemic. Over the past few years, the school's achievements have also been quite encouraging both at the provincial and national levels. Finally, this school also runs a student exchange program in America for one year. Puspendik data for 2019, this high school is ranked 23 in the average 2019 National Examination score at the provincial level (https://hasilun.puspendik.kemdikbud.go.id/\#2019!sma!capaian!24\&99\&999!T\&T\&1\&T\&1\&unbk!3! \&). This school is ranked 2nd out of 26 schools in the Ende district at the district level. The students' character selected in this study was uniform in terms of academic and social abilities. Students are used to doing problem-solving test questions but have never conducted a student perception questionnaire about the role of physics learning in problem-solving and peer assessment.

\section{Result and Discussion}

Questionnaires on student perceptions of learning and peer assessment in this study were conducted to describe students' perceptions of solving physics problems seen from the factors of student involvement in peer assessment and questionnaires on student perceptions of learning as well as teacher and student perceptions of student involvement in solving physics problems. Based on the research results, the results obtained from descriptive statistics obtained by teachers from students' problem-solving tests are presented in Table 2.

Table 2. Descriptive Statistics of Problem-solving Ability Test

$\begin{array}{cc}\text { Number of Students }(\mathrm{N}) & 25,00 \\ \text { Mean } & 53.07 \\ \text { Standard Deviation } & 10.85 \\ \text { Minimum } & 32.38 \\ \text { Maximum } & 80,00\end{array}$

Based on Table 2, it is found that the average value of the problem-solving ability test results of 25 students has an average of 53.07 and has a standard deviation of 10.85 with the lowest test result of 32.38 and the highest score of 80.00 . Furthermore, the following is a table of results of the analysis of the questionnaire scores of students' perceptions of learning, shown in Table 3.

Based on Table 3, it was found that the results of the analysis of the questionnaire scores on student perceptions of learning were scored by students as many as ten core items, each of which has an average of student answers. The highest score percentage in the TM (Unhelpful) section is 
item number 8 at 19.20\%, and the lowest is item number 1 at 1.33\%. The highest percentage score on the SM (Slightly Helpful) section is item number 1 at $64.00 \%$, and the lowest percentage on item number 5 is $26.00 \%$. The highest percentage score on the BM (Very Helpful) section is item number 5 at $70.00 \%$, and the lowest percentage on item number 1 is $34.67 \%$.

Table 3. The results of the analysis of students' perception of the questionnaire scores on learning

\begin{tabular}{clccc}
\hline \multirow{2}{*}{ No. } & \multicolumn{1}{c}{ Item } & \multicolumn{2}{c}{ Rata-rata Jawaban (Presentase) } \\
\cline { 3 - 5 } & & TM & SM & BM \\
\hline 1. & Whole class & 1,33 & 64,00 & 34,67 \\
2. & Class activity & 6,22 & 37,33 & 56,44 \\
3. & Task, learning activity, test & 10,29 & 39,81 & 49,90 \\
4. & Class source & 12,44 & 39,11 & 48,44 \\
5. & Information given to students & 4,00 & 26,00 & 70,00 \\
6. & Support for students as independent learning & 8,00 & 31,00 & 61,00 \\
7. & Students' understanding of the material in class & 15,60 & 41,60 & 42,80 \\
8. & Student's skill improvement & 19,20 & 44,80 & 36,00 \\
9 & The effect of learning on student attitudes & 14,40 & 36,00 & 49,60 \\
10. & Student's learning process & 12,67 & 43,33 & 44,00 \\
\hline
\end{tabular}

Table 4. Descriptive statistics of peer assessment results

\begin{tabular}{cc}
\hline Number of Students (N) & 25,00 \\
Mean & 65,10 \\
Standard Deviation & 10,69 \\
Minimum & 43,81 \\
Maximum & 93,33 \\
\hline
\end{tabular}

Table 5. Analysis results of student perception of peer assessment

\begin{tabular}{|c|c|c|c|}
\hline \multirow{2}{*}{$\begin{array}{c}\text { No. } \\
\text { Item } \\
\text { Choice }\end{array}$} & \multirow[t]{2}{*}{ Item Choice } & \multicolumn{2}{|c|}{$\begin{array}{c}\text { Percentage } \\
(\%)\end{array}$} \\
\hline & & Yes & No \\
\hline 1. & The hardest part of Physics is Parabolic Motion. & 88 & 12 \\
\hline 2. & I'm an expert on the topic of Parabolic Motion. & 16 & 84 \\
\hline 3. & I like the topic of Parabolic Motion. & 56 & 44 \\
\hline 6. & I am aware and understand the purpose of using peer assessment in Physics class. & 68 & 32 \\
\hline 9. & I can judge my friends' work well. & 72 & 28 \\
\hline 10. & $\begin{array}{l}\text { The discussion about Parabolic Motion really helped me in understanding class } \\
\text { assignment questions. }\end{array}$ & 96 & 4 \\
\hline 11. & I can judge my peers' work well. & 60 & 40 \\
\hline 12. & The scoring rubric is easy to apply. & 36 & 64 \\
\hline 13. & I can judge my peers' work fairly. & 88 & 12 \\
\hline 14. & I feel more comfortable writing feedback for my friends than rating it. & 36 & 64 \\
\hline 15. & $\begin{array}{l}\text { Assessing my colleague's work makes me more aware of physics concepts, especially } \\
\text { in the topic of learning Parabolic Motion. }\end{array}$ & 76 & 24 \\
\hline 16. & I understand the feedback given to me. & 48 & 52 \\
\hline 17. & The feedback given to me is accurate. & 64 & 36 \\
\hline 18. & The feedback given by my friend is fair. & 72 & 28 \\
\hline 19. & The feedback given to me really helps me improvise my work. & 84 & 16 \\
\hline 20. & I'm not sure how to revise my work after reading the feedback. & 48 & 52 \\
\hline 21. & I understand the topic better after reading feedback and making revisions to my work. & 68 & 32 \\
\hline 22. & I'm happy to give peer feedback. & 76 & 24 \\
\hline & Average & 65 & 35 \\
\hline
\end{tabular}

The following shows the results of the peer assessment conducted by students against a friend. Peer assessment carried out on the results of student work on the problem-solving test can be seen in Table 4. 
Based on Table 4, it is found that the average value of the peer assessment results from 25 students has an average of 65.10 and has a standard deviation of 10.69, with the lowest test result being 43.81 and the highest score being 93.33 . The average peer assessment value differs from the problem-solving ability test score of 12.04 . This means that the difference in assessment is $>10$ so that the assessment is successful or the student's assessment is close to the assessment made by the teacher. For the effectiveness of the peer assessment, it can be seen from the student's response questionnaire regarding the implementation of the peer assessment of each item is high.

The following are the research results conducted by students for peer assessment which are presented in Table 5. Table 5, which is the result of the analysis of student perceptions of peer assessment conducted by students to their friends, obtained an average of $65 \%$ of students answered statements with "yes" answers and an average of $35 \%$ of students answered statements with "no" answers. Some students concentrate on deepening their understanding. The students rated peer assessment as a meaningful activity; this opinion was in line with (Handayani et al., 2019; Pitt \& Norton, 2017), who found that some students failed to record the feedback given by the teacher and made them less understanding of the feedback explained. by the teacher. But we believe that every student has the ability to judge the products of their friends and separate their emotional state. The involvement of friends in this assessment process should go beyond just assessing the work of friends and comparing their grades with those of the teacher.

Based on the research results, students' problem-solving abilities were obtained, with the results of 53.06 being included in the sufficient category. The average score of the problem-solving test results is different from the average score of the peer assessment results because students are not used to using peer assessment in learning. This is because students are not used to giving grades (64\%) and using an assessment rubric (64\%). Lack of training to students on how to provide good and appropriate peer assessment is a key factor in the success of peer assessment (Veugen et al., 2021). This is in line with the findings made by Edwards (2013), which states that training students on instruction in peer assessment will improve the quality of peer assessment itself and can provide good feedback for student learning (Veugen et al., 2021).

The results of the problem-solving analysis in the questionnaire on students' perceptions of learning obtained the results as shown in Figure 1.

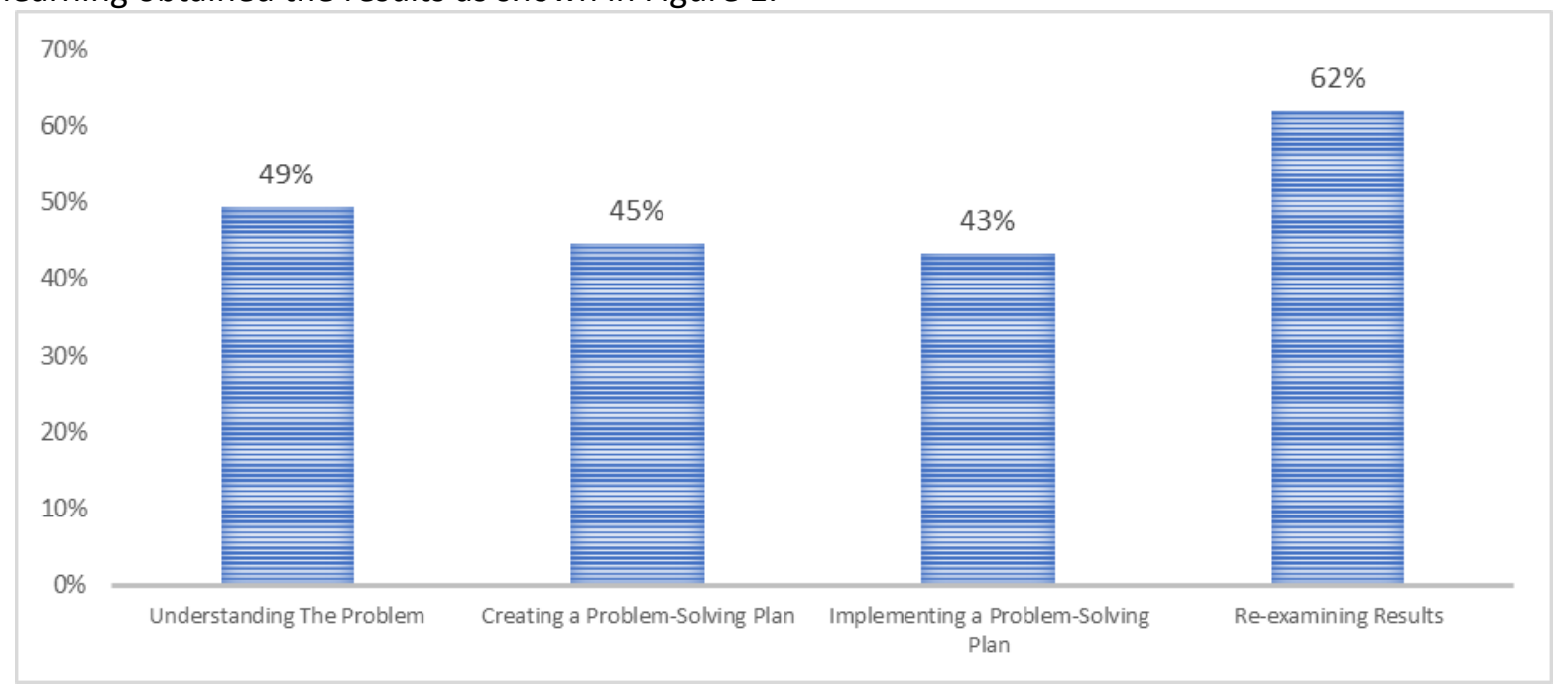

Figure 1. Analysis Data of Problem-Solving Ability

Based on Figure 1, the problem-solving ability, in general, is in the sufficient category of $50 \%$. The highest score in the problem-solving aspect is re-examining the results by $62 \%$, and the lowest is implementing a problem-solving plan by $43 \%$.

In the indicator of understanding the problem, students are asked to reread the existing questions, understand the meaning of the questions, and understand the basic concepts to answer the questions (Omar et al., 2018). In this indicator, the average score achieved based on the results 
of the questionnaire on students' perceptions of learning is $49 \%$ and is categorized as sufficient. This shows the difficulty of students in understanding the meaning and basic concepts of the questions given. 10 out of 25 students were able to understand the meaning of the questions, and 13 out of 25 students had understood the basic concepts asked in the questions. This shows that there are still many students who have not been able to master the concept and purpose of the questions, so students are often wrong in determining the variables that are known and asked in the questions (Park, 2020).

The indicator of making a problem-solving plan obtains a percentage of $45 \%$ and is categorized as sufficient. This shows that the indicators of students' ability to plan problem-solving are not as expected. Based on the results of the questionnaire on students' perceptions of learning, students had difficulties in writing down variables related to the questions (17 students), making pictures and problem-solving diagrams (14 students), and still using trial and error patterns in solving problems. In this indicator, the ability to understand students' concepts is the main requirement in solving problem-solving problems (Rodzalan \& Saat, 2015). Students still often use mathematical equations as problem-solving solutions rather than analyzing concepts based on applicable physical principles and laws (Park, 2020). This is because learning that occurs in the classroom focuses more on how students can remember knowledge (formulas, symbols, and meanings) rather than analyzing the knowledge itself (Rodzalan \& Saat, 2015).

The indicator of implementing the problem-solving plan gets a percentage of $43 \%$ (enough category) and is the lowest indicator. This is because students still find it difficult to enter the quantities contained in the problem into the problem-solving process (19 students) and students rely more on formulas than basic concepts to solve problems ( 17 students). This can be seen in Figure 2.

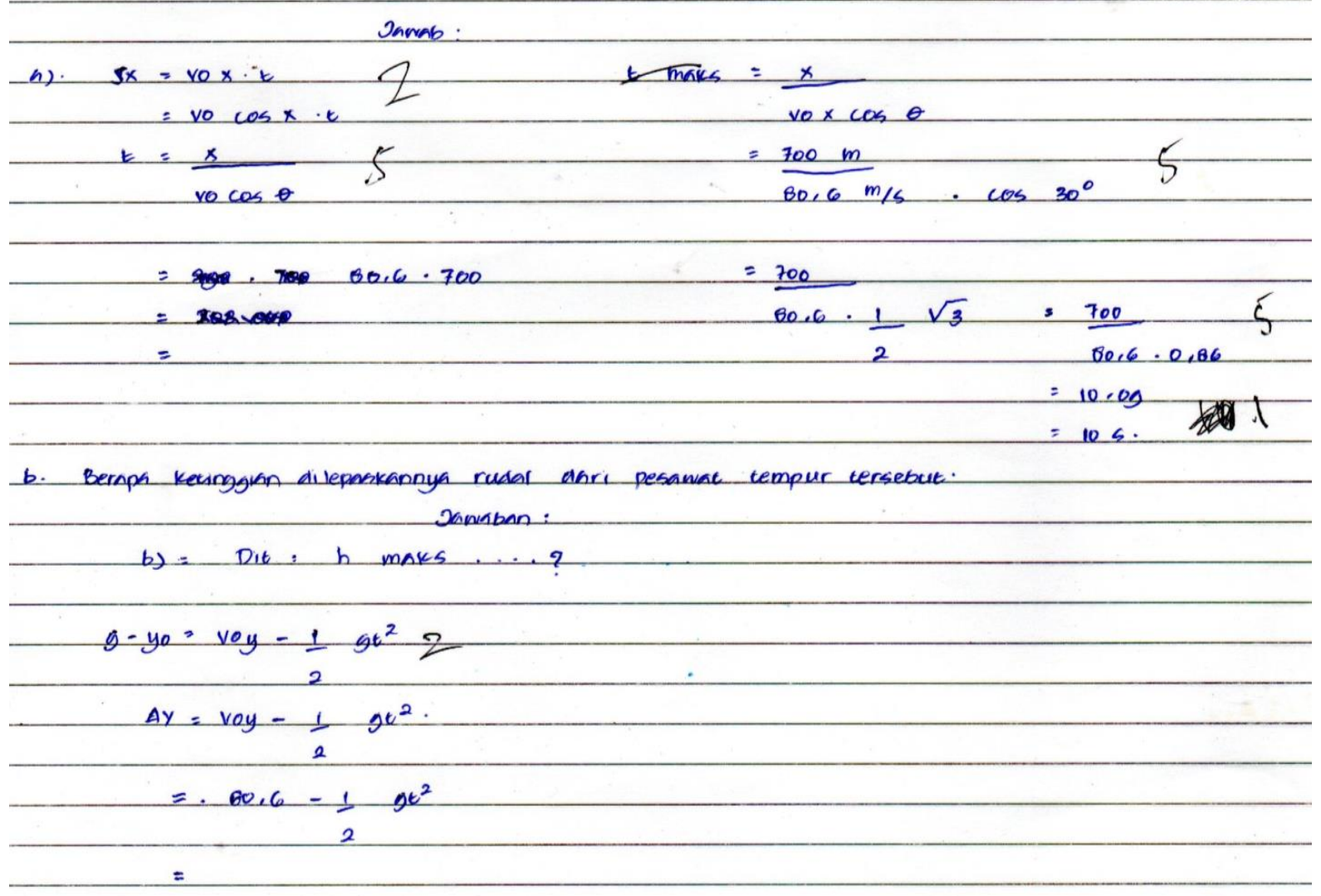

Figure 2. Results of Student's Answer

In Figure 2, it can be seen the tendency of students to master and memorize formulas but have not mastered the concept. In the answer section "b", it is seen that students do not understand the basic concept of yo (initial height), so students cannot solve the questions given. This is in line with Rodzalan \& Saat (2015), which says that problem-solving learning must be able to lead students to a deep understanding of the material being taught. This is because understanding concepts is the basis 
for students to be able to think critically (Park, 2020; Rodzalan \& Saat, 2015; Veugen et al., 2021). Problem-solving and critical thinking skills allow students to be able to solve complex problemsolving problems (Rodzalan \& Saat, 2015). Mastery of concepts is an important aspect in solving problems (Guo et al., 2020; Liaw et al., 2021). The last indicator is to re-examine the results. The results of the analysis obtained were $62 \%$ (high category). Sixteen students re-examined the steps for solving the problem, and 15 students looked back at the answers they got.

Prior to the research, the students had never heard of the term peer assessment but had experienced an informal peer assessment process through their peer-reviewed work. Students feel that assessing peer work is useful because when they understand mistakes made in work, they can teach them to their peers (Sluijsmans et al., 2001). In other words, they can help their colleagues who have difficulty understanding or solving certain physics problems (Zhang, 2020) and help them improve their understanding by teaching them feedback (Alias et al., 2015). An explanation of how peer assessment is guided is complemented by a handout on the learning objectives and a list of general success criteria expected in the topic (Omar et al., 2018). Students are given training on assessment and setting of success criteria to familiarize themselves with the rubric and assess peer work against the criteria (Omar et al., 2018).

The results of the analysis were obtained for the assessments made by students compared to the assessments made by the teacher. For the effectiveness of peer assessment, it can be seen from the student response questionnaire regarding the implementation of the peer assessment of each item is high. This is shown from the questionnaire on the effectiveness of the implementation of peer assessment, each item $<65 \%$. The percentage of effectiveness for each item can be seen in table 5 . From the research data found in table 5 , the majority of students think that parabolic motion is the most difficult material that students learn in physics class. The difficulty of students in the parabolic motion material resulted in the average score obtained by the students' scores in the problemsolving test of 53.06. To overcome this problem, the teacher and the students held a joint discussion regarding the parabolic motion material. The majority of students benefit from the discussion. This is because there is a pattern of peer tutoring in the transfer of knowledge by fellow students (Song, 2018). This pattern of knowledge transfer, feedback was given by peer students (Alias et al., 2015), $84 \%$ of students gave a positive response. In addition to peer tutors, students also received positive responses to the assessment of their friends' work so that $76 \%$ of students were able to master the physics concepts related to parabolic motion.

The results of this study have provided insight into the impact of a student-centred learning approach through formative assessment (Zhang, 2020). A possible reason that contributed to the improvement in this test is the reflective rumination activity (Hansen \& Ringdal, 2018) that occurs during any part of the peer assessment process. Exposure to different quality physics materials to students through assessment activities in a group (Rodzalan \& Saat, 2015) encourages students to reflect on their learning outcomes while making an assessment of their friends' learning outcomes (Hansen \& Ringdal, 2018). This indirectly leads students to measure their current level of understanding of others (Sluijsmans et al., 2001) and initiate changes for improvement (K. Daniels et al., 2019). Reflective practices have contributed to increasing understanding through learning (Adarkwah, 2021; Song, 2018). Discussions incorporated into peer assessment in groups have helped students in understanding approaches to solve certain physics problems. Interaction with peers in productive discussions allows students to share their thoughts and promotes critical thinking (Veugen et al., 2021). In addition, Pugalee (2004) explains that students can think quickly or heavily when using mathematical ideas by writing.

Time factors such as one-hour lessons may have limited students from using opportunities in peer assessment to reflect deeply on the work of others (Omar et al., 2018). Peer distraction and motivation can affect students' involvement in the process of assessing their work. Apart from the previous discussion of the success criteria, it is hoped that students will absorb the criteria and will be able to solve the same problems. The time factor also seems to be a concern when implementing an intervention using a peer assessment approach, especially when physics lessons are limited by a series of the syllabus to be completed because peer assessment is a time-consuming process. 
Generally, students find peer assessment and receive feedback to be useful in their learning regardless of the teacher or their peers. They value peer assessment as an opportunity to learn different approaches and strategies from their peers in completing their tasks (Logan, 2009; Tsivitanidou et al., 2018; Zevenbergen, 2001).

\section{Conclusion}

Based on the explanation above, it can be concluded that the average score of the problemsolving test for parabolic motion material is 53.06 and has a standard deviation of 10.84 with the lowest test result of 32.3 and the highest score of 80 . The average student perception questionnaire on concept solving learning by $10.4 \%$ of students thought that the learning carried out did not help (TM), $40.3 \%$ of students thought that the learning carried out was a little helpful (SM), and $49.3 \%$ of students thought that the learning carried out is very helpful in improving concept solving. Furthermore, the average value of the peer assessment results from 25 students has an average of 65.10 and has a standard deviation of 10.69 with the lowest test result of 43.8 and the highest score of 93.3. The results of the analysis of student perceptions of peer assessment conducted by students to their friends obtained an average of $65 \%$ of students answering statements with "yes" answers and an average of $35 \%$ of students answering statements with "no" answers.

The students' problem-solving ability on the re-examining indicator obtained the highest percentage of $62 \%$, and the indicator of implementing the problem-solving plan obtained the lowest percentage of $43 \%$. In general, students' problem-solving abilities are in the sufficient category by $50 \%$. Future research is expected to provide training in advance on peer assessment by providing training on how to give value to a friend's work based on instructions and assessment criteria that have been made.

\section{References}

Adarkwah, M. A. (2021). The power of assessment feedback in teaching and learning: a narrative review and synthesis of the literature. In SN Social Sciences (Vol. 1, Issue 3). Springer International Publishing. https://doi.org/10.1007/s43545-021-00086-w

Alias, M., Masek, A., \& Salleh, H. H. M. (2015). Self, peer and teacher assessments in problem based learning: Are they in agreements? Procedia - Social and Behavioral Sciences, 204(November 2014), 309-317. https://doi.org/10.1016/j.sbspro.2015.08.157

Bahar, R., Istiyono, E., Widihastuti, W., Munadi, S., Nuryana, Z., \& Fajaruddin, S. (2021). Analisis karakteristik soal ujian sekolah hasil musyawarah guru matematika di Tasikmalaya. AKSIOMA: Jurnal Program Studi Pendidikan Matematika, 10(4), 2660. https://doi.org/10.24127/ajpm.v10i4.4359

Berge, M., \& Danielsson, A. T. (2013). Characterising learning interactions: A study of university students solving physics problems in groups. Research in Science Education, 43(3), 1177-1196. https://doi.org/10.1007/s11165-012-9307-0

Bloxham, S., \& West, A. (2004). Understanding the rules of the game: Marking peer assessment as a medium for developing students' conceptions of assessment. Assessment and Evaluation in Higher Education, 29(6), 721-733. https://doi.org/10.1080/0260293042000227254

Chang, C. Y. (2010). Does problem solving = prior knowledge + reasoning skills in earth science? An exploratory study. Research in Science Education, 40(2), 103-116. https://doi.org/10.1007/s11165-008-9102-0

Dall'Alba, G. (1986). Learning strategies and the learner's approach to a problem solving task. Research in Science Education, 16(1), 11-20. https://doi.org/10.1007/BF02356813

Daniels, K., Elliott, C., Finley, S., \& Chapman, C. (2019). Learning and teaching in higher education. In Learning and Teaching in Higher Education (Issue 1). Edward Elgar Publishing. https://doi.org/10.4337/9781788975087 
Daniels, L. M., Goegan, L. D., \& Parker, P. C. (2021). The impact of COVID-19 triggered changes to instruction and assessment on university students' self-reported motivation, engagement and perceptions. Social Psychology of Education, 24(1), 299-318. https://doi.org/10.1007/s11218021-09612-3

Demirhan, E., \& Şahin, F. (2021). The effects of different kinds of hands-on modeling activities on the academic achievement, problem-solving skills, and scientific creativity of prospective science teachers. Research in Science Education, 51(S2), 1015-1033. https://doi.org/10.1007/s11165019-09874-0

Edwards, J. G. H. (2013). Peer assessment in the classroom. In The Companion to Language Assessment (pp. 730-750). John Wiley \& Sons, Inc. https://doi.org/10.1002/9781118411360.wbcla002

Ezzahra, K. F., Islam, O., \& Mohamed, R. (2015). Self-assessment of the progress of thesis for the PhD students in the Moroccan University. Procedia - Social and Behavioral Sciences, 197(February), 1789-1795. https://doi.org/10.1016/j.sbspro.2015.07.237

Fadhilah, F., Effendi, Z. M., Ridwan, R., \& Alias, M. (2019). Effectiveness of DILA learning model application on applied physics course in the department of mining engineering. Jurnal Pendidikan Fisika Indonesia, 15(1), 46-51. https://doi.org/10.15294/jpfi.v15i1.15389

Freitas, I. M., Jiménez, R., \& Mellado, V. (2004). Solving physics problems: The conceptions and practice of an experienced teacher and an inexperienced teacher. Research in Science Education, 34(1), 113-133. https://doi.org/10.1023/B:RISE.0000021000.61909.66

Goh, W. W., Tang, S. F., \& Lim, C. L. (2016). Assessment for Learning Within and Beyond the Classroom. In Assessment for Learning Within and Beyond the Classroom (pp. 61-70). Springer Singapore. https://doi.org/10.1007/978-981-10-0908-2_6

Guiaya, M. T., \& Bueno, D. C. (2019). Strategic questioning as formative assessment in teaching mathematics grade 9 learners. Institutional Multidisciplinary Research and Development Journal, 2(June), 149-152. https://doi.org/10.13140/RG.2.2.21743.89769

Guo, P., Saab, N., Post, L. S., \& Admiraal, W. (2020). A review of project-based learning in higher education: Student outcomes and measures. International Journal of Educational Research, 102(April), 101586. https://doi.org/10.1016/j.ijer.2020.101586

Handayani, R. D., Genisa, M. U., \& Triyanto. (2019). Empowering physics students' performance in a group discussion through two types of peer assessment. International Journal of Instruction, 12(1), 655-668. https://doi.org/10.29333/iji.2019.12142a

Hansen, G. (2020). Formative assessment as a collaborative act. Teachers` intention and students` experience: Two sides of the same coin, or? Studies in Educational Evaluation, 66(July), 100904. https://doi.org/10.1016/j.stueduc.2020.100904

Hansen, G., \& Ringdal, R. (2018). Formative assessment as a future step in maintaining the masteryapproach and performance-avoidance goal stability. Studies in Educational Evaluation, 56(November 2017), 59-70. https://doi.org/10.1016/j.stueduc.2017.11.005

Heredia, S. C., Furtak, E. M., Morrison, D., \& Renga, I. P. (2016). Science teachers' representations of classroom practice in the process of formative assessment design. Journal of Science Teacher Education, 27(7), 697-716. https://doi.org/10.1007/s10972-016-9482-3

Jamaludin, A., \& Hung, D. (2017). Problem-solving for STEM learning: navigating games as narrativized problem spaces for 21 st century competencies. Research and Practice in Technology Enhanced Learning, 12(1), 1-14. https://doi.org/10.1186/s41039-016-0038-0

Jones, B. D., \& Carter, D. (2019). Relationships between students' course perceptions, engagement, and learning. Social Psychology of Education, 22(4), 819-839. https://doi.org/10.1007/s11218019-09500-x

Kelly, S. (2007). Classroom discourse and the distribution of student engagement. Social Psychology 
of Education, 10(3), 331-352. https://doi.org/10.1007/s11218-007-9024-0

Ketonen, L., Hähkiöniemi, M., Nieminen, P., \& Viiri, J. (2020). Pathways through peer assessment: implementing peer assessment in a lower secondary physics classroom. International Journal of Science and Mathematics Education, 18(8), 1465-1484. https://doi.org/10.1007/s10763-01910030-3

Laskar, J., \& Robutel, P. (2000). High order symplectic integrators for perturbed Hamiltonian systems. Learning Environments Research, 1(June 2014), 293-319.

Lee, K.-W. (1986). Case studies of teaching problem solving. Research in Science Education, 16(1), 2130. https://doi.org/10.1007/BF02356814

Leeuwenkamp, K. J. G., Brinke, D. J., \& Kester, L. (2019). Students' perceptions of assessment quality related to their learning approaches and learning outcomes. Studies in Educational Evaluation, 63(July), 72-82. https://doi.org/10.1016/j.stueduc.2019.07.005

Liaw, H., Yu, Y.-R., Chou, C.-C., \& Chiu, M.-H. (2021). Relationships between facial expressions, prior knowledge, and multiple representations: a case of conceptual change for kinematics instruction. Journal of Science Education and Technology, 30(2), 227-238. https://doi.org/10.1007/s10956-020-09863-3

Liu, N., \& Carless, D. (2006). Peer feedback: the learning element of peer assessment. Teaching in Higher Education, 11(3), 279-290. https://doi.org/10.1080/13562510600680582

Logan, E. (2009). Self and peer assessment in action. Practitioner Research in Higher Education, 3(1), 29-35. http://insight.cumbria.ac.uk/id/eprint/3306/

Lu, J., \& Law, N. (2012). Online peer assessment: Effects of cognitive and affective feedback. Instructional Science, 40(2), 257-275. https://doi.org/10.1007/s11251-011-9177-2

Milbourne, J., \& Wiebe, E. (2018). The role of content knowledge in ill-structured problem solving for high school physics students. Research in Science Education, 48(1), 165-179. https://doi.org/10.1007/s11165-016-9564-4

Miller, P. J. (2003). The effect of scoring criteria specificity on peer and self-assessment. Assessment \& Evaluation in Higher Education, 28(4), 383-394. https://doi.org/10.1080/0260293032000066218

Molway, L. (2021). Measuring effective teaching: Student perceptions of their modern languages lessons in England. System, 97, 102440. https://doi.org/10.1016/j.system.2020.102440

Nouwen, W., \& Clycq, N. (2019). The role of social support in fostering school engagement in urban schools characterised by high risk of early leaving from education and training. Social Psychology of Education, 22(5), 1215-1238. https://doi.org/10.1007/s11218-019-09521-6

Omar, D. S. N. P., Shahrill, M., \& Sajali, M. Z. (2018). The use of peer assessment to improve students' learning of geometry. European Journal of Social Science Education and Research, 5(2), 187206. https://doi.org/10.2478/ejser-2018-0047

Panadero, E., \& Dochy, F. (2014). Student self-assessment: assessment, learning and empowerment. Assessment \& Evaluation in Higher Education, 39(7), 895-897. https://doi.org/10.1080/02602938.2013.871412

Papinczak, T., Young, L., \& Groves, M. (2007). Peer assessment in problem-based learning: A qualitative study. Advances in Health Sciences Education, 12(2), 169-186. https://doi.org/10.1007/s10459-005-5046-6

Park, M. (2020). Students' problem-solving strategies in qualitative physics questions in a simulationbased formative assessment. Disciplinary and Interdisciplinary Science Education Research, 2(1), 1-13. https://doi.org/10.1186/s43031-019-0019-4

Pitt, E., \& Norton, L. (2017). 'Now that's the feedback I want!' Students' reactions to feedback on graded work and what they do with it. Assessment and Evaluation in Higher Education, 42(4), 499-516. https://doi.org/10.1080/02602938.2016.1142500 
Ploegh, K., Tillema, H. H., \& Segers, M. S. R. (2009). In search of quality criteria in peer assessment practices. Studies in Educational Evaluation, 35(2-3), 102-109.

https://doi.org/10.1016/j.stueduc.2009.05.001

Pöysä-Tarhonen, J., Awwal, N., Häkkinen, P., \& Otieno, S. (2021). Joint attention behaviour in remote collaborative problem solving: exploring different attentional levels in dyadic interaction. Research and Practice in Technology Enhanced Learning, 16(1). https://doi.org/10.1186/s41039-021-00160-0

Pugalee, D. K. (2004). A comparison of verbal and written descriptions of students' problem solving processes. Educational Studies in Mathematics, 55(1-3), 27-47. https://doi.org/10.1023/B:EDUC.0000017666.11367.c7

Quin, D., Hemphill, S. A., \& Heerde, J. A. (2017). Associations between teaching quality and secondary students' behavioral, emotional, and cognitive engagement in school. Social Psychology of Education, 20(4), 807-829. https://doi.org/10.1007/s11218-017-9401-2

Reinholz, D. (2016). The assessment cycle: a model for learning through peer assessment. Assessment and Evaluation in Higher Education, 41(2), 301-315. https://doi.org/10.1080/02602938.2015.1008982

Rodzalan, S. A., \& Saat, M. M. (2015). The perception of critical thinking and problem solving skill among Malaysian undergraduate students. Procedia - Social and Behavioral Sciences, 172(2012), 725-732. https://doi.org/10.1016/j.sbspro.2015.01.425

Scherer, R., \& Beckmann, J. F. (2014). The acquisition of problem solving competence: evidence from 41 countries that math and science education matters. Large-Scale Assessments in Education, 2(1), 10. https://doi.org/10.1186/s40536-014-0010-7

Schildkamp, K., van der Kleij, F. M., Heitink, M. C., Kippers, W. B., \& Veldkamp, B. P. (2020). Formative assessment: A systematic review of critical teacher prerequisites for classroom practice. International Journal of Educational Research, 103(June), 101602. https://doi.org/10.1016/j.ijer.2020.101602

Shin, N., Bowers, J., Krajcik, J., \& Damelin, D. (2021). Promoting computational thinking through project-based learning. Disciplinary and Interdisciplinary Science Education Research, 3(1). https://doi.org/10.1186/s43031-021-00033-y

Sluijsmans, D. M. A., Moerkerke, G., van Merrieboer, J. J. G., \& Dochy, F. J. R. C. (2001). Peer Assessment in Problem-Based Learning. Studies in Educational Evaluation, 27(01), 153-173. https://doi.org/10.4324/9781315042039-36

Song, Y. (2018). Improving primary students' collaborative problem solving competency in projectbased science learning with productive failure instructional design in a seamless learning environment. Educational Technology Research and Development, 66(4), 979-1008. https://doi.org/10.1007/s11423-018-9600-3

Spoon, R., Rubenstein, L. D. V., \& Terwillegar, S. R. (2021). Team effectiveness in creative problem solving: Examining the role of students' motivational beliefs and task analyses in team performance. Thinking Skills and Creativity, 40(January), 100792. https://doi.org/10.1016/j.tsc.2021.100792

Tan, A.-L., Teo, T. W., Choy, B. H., \& Ong, Y. S. (2019). The S-T-E-M Quartet. Innovation and Education, 1(1), 1-14. https://doi.org/10.1186/s42862-019-0005-x

Tapingkae, P., Panjaburee, P., Hwang, G. J., \& Srisawasdi, N. (2020). Effects of a formative assessment-based contextual gaming approach on students' digital citizenship behaviours, learning motivations, and perceptions. Computers and Education, 159(August), 103998. https://doi.org/10.1016/j.compedu.2020.103998

Tsivitanidou, O. E., Constantinou, C. P., Labudde, P., Rönnebeck, S., \& Ropohl, M. (2018). Reciprocal peer assessment as a learning tool for secondary school students in modeling-based learning. European Journal of Psychology of Education, 33(1), 51-73. https://doi.org/10.1007/s10212- 


\section{7-0341-1}

Veugen, M. J., Gulikers, J. T. M., \& den Brok, P. (2021). We agree on what we see: Teacher and student perceptions of formative assessment practice. Studies in Educational Evaluation, 70(October 2020), 101027. https://doi.org/10.1016/j.stueduc.2021.101027

Voinea, L. (2018). Formative assessment as assessment for learning development. Revista de Pedagogie - Journal of Pedagogy, LXVI(1), 7-23. https://doi.org/10.26755/RevPed/2018.1/7

Wancham, K., \& Tangdhanakanond, K. (2020). Effects of feedback types and opportunities to change answers on achievement and ability to solve physics problems. Research in Science Education, Shute 2007. https://doi.org/10.1007/s11165-020-09956-4

Yurdabakan, I., \& Olgun, M. (2011). The influence of peer and self-assessment on learning and metacognitive knowledge: consequential validity. International Journal on New Trends in Education and Their Implications, 2(4), 44-57.

http://www.ajindex.com/dosyalar/makale/acarindex-1423904122.pdf

Zevenbergen, R. (2001). Peer assessment of student constructed posters: assessment alternatives in preservice mathematics education. Journal of Mathematics Teacher Education, 4(1994), 95113. https://doi.org/10.1023/A:1011401532410

Zhang, X. (2020). Assessment for learning in constrained contexts: How does the teacher's selfdirected development play out? Studies in Educational Evaluation, 66(July), 100909.

https://doi.org/10.1016/j.stueduc.2020.100909 